OBSERVATIONS ON COPPER POISONING IN WINTER FIOUNDER 


\section{Histological and Electron Microscopical Observations on Copper Poisoning in the Winter Flounder \\ (Pseudopleuronectes americanus)}

by

Jeremy Baker, B.Sc.

A thesis submitted to the Faculty of Graduate Studies and Research of McGill University in partial fulfillment of the requirements for the degree of Master of Science in Marine Science.

Marine Sciences Centre, McGill University, Montreal, Canada.

December, 1969 
Table of Contents

Table of Contents

$i$

List of" Figures

Abstract in English

ii

Abstract in French

iv

Introduction

vi

Materials and Methods

1

Results

3

6

Discussion

37

Summary

43

Acknowledgements

45

References Cited

46 


\section{List of Figures}

\section{$\underline{\text { Page }}$}

\section{Light Microscope}

1. Control Iiver. 9

2. Effects of $1000 \mu \mathrm{gm} / 1$ of copper on liver. 9

3. Control kidney and haemopoetic tissue. 11

4. Effects of $3200 \mu \mathrm{gm} / 1$ of copper on kidney and haemopoetic tissue. 11

5. Control gills. 14

6. Effects of $3200 \mu \mathrm{gm} / 1$ of copper on gills. 14

7. Control gill epithelium and mucus cells. 16

8. Effects of $180 \mu \mathrm{gm} / 1$ of copper on gill lamellae. 16

9. Effects of $180 \mathrm{\mu gm} / 1$ of copper on gill lamellae. 16

\section{Electron Microscope}

10. Control gill lamella. 19

11. Control gill epithelium cell. 21

12. Control gill epithelium; mucus cell. 23

13. Effects of $180 \mu \mathrm{gm} / \mathrm{l}$ of copper on gill lamella; chloride cell. 25

14. Effects of $180 \mathrm{\mu gm} / \mathrm{l}$ of copper on gill lamella; myelin bodies.

15. Effects of $180 \mu \mathrm{gm} / \mathrm{l}$ of copper on gill lamella; autophagosomes . 
16. Effects of $180 \mu \mathrm{gm} / 1$ of copper on gill lamella; vesicular system.

17. Effects of $180 \mu \mathrm{gm} / 1$ of copper on gill lamella; increased particulate matter.

18. Effects of $180 \mu \mathrm{gm} / 1$ of copper on gill lamella; vacuoles.

19. Fate of each fish in different copper concentrations. Survival time in hours is plotted against copper concentrations in $\mu \mathrm{gm} / \mathrm{litre}$. 
ABSTRACT

Experiments were made to investigate any possible morphological changes in Winter Flounder, Pseudopleuronectes americanus, exposed to high, medium and low levels of copper. It was found that a high level $(3200 \mu \mathrm{g} / \mathrm{l})$ of exogenous copper was lethal and a low level (180 $\mu \mathrm{gm} / \mathrm{l}$ ) was sub-lethal. Emphasis was placed on the experiment involving low levels of copper since there is a lack of information on sub-lethal effects of heavy metal poisoning to fish.

Tissues from all three groups of poisoned fish and control fish were examined under a light microscope. An additional study of gill tissue from the sub-lethal group was made using an electron microscope in order to determine the effects of low doses of copper on gill ultrastructure. High and medium levels of copper caused fatty metamorphosis in the liver, necrosis in the kidney, destruction of the haemopoetic tissue and gross changes in gill architecture. Seven other structures and organs showed no copper-induced morphological changes. Low levels of copper caused the epithelial layers of gill lamellae to be vacuolated and the basilamellar regions to be reduced in thickness. Lamella mucus cells were few when compared to control specimens, and chloride cells appeared in their stead.

A study of gill tissue from the sub-lethal group made under electron microscopes revealed vacuolated cytoplasm, myelinlike figures, various membrane-bound vesicles and a reduction in the thickness of the apical homogeneous layers in the gills. 
Typical chloride-excreting cells replaced mucus cells and there was an increase in particulate matter adhering to the epithelial cell outer membranes. 
On a réalisé des expériénces afin d'examiner les changements morphologiques possibles chez le carrelet d'hiver, Pseudapleuronectes americanus, aprés exposition à des doses de cuivre élevées, moyennes et réduites. On a trouvé qu'une dose élevée de cuivre exogène (3200 ug/l) est mortelle tandis qu'une dose réduite (180 ugm/I) ne cause pas le décès. On a insisté sur les expériences concernant les effets de doses réduites de cuivre à cause du manque d'information existant sur les effets marginaux de l8empoisonement par métaux lourds chez le poisson.

Des tissus provenant de chacun des trois groupes de poisson contaminés et des contrôles furent examinés lilaide d'un microscope optique. Une étude supplémentaire de tissus branchiaux provenant du groupe marginal fut conduite au moyen d'un microscope électronique afin de déterminer les effets de doses réduites de cuivre sur les ultrastructures branchiales.

Des doseséélevées et moyennes de cuivre ont déterminé des métamotphosis graisseuses dans le foie, une nécrose du rein, une destruction du tissu haemopatique et des changements radicaux dans I'architecture branchiale. Sept autres structures ou organes ne révè̀lèrent aucun changements imputables au cuivre. Des doses réduites de cuivre provoquèrent des vacuoles dans les lamelles branchiales et une réduction dans l'épaisseur des régions sous-jacents. Les cellules muqueuses des lamelles étaient rares comparées aux échantillons de contròle, et à leur place des cellules àchlorure firent apparition. 
Une étude au microscope électronique du groupe marginal mit en évidence une vacuolization du cytoplasm, des figures du genre myelin, diverses sortes de vésicules attachées àla membrane et une réduction dans 1 I'épaisseur des couches homogènes dans les branchies. Des cellules types àexcrétion de chlorure prirent la place des cellules muqueuses et il y a eut une augmentation du nombre des particules adhérant aux membranes extérieures de la cellule épithéiale. 
INTRODUCTI ON

A small amount of copper, 3 to $20 \mu \mathrm{gm} / \mathrm{l}$. normally is present in the marine envi ronment (Chow, T. J. and T. G. Thompson, 1952 and Chow, T. J. and T. G. Thompson, 1954). Copper is an essential dietary component of both animals and plants, where it plays an essential enzymatic role in several enzyme systems. As with many other compounds that are needed by organisms in minute amounts, copper in small amounts is necessary but in larger than these trace amounts it becomes an enzyme poison (Scheinberg and Sternleib, 1960). Plants are the usual source of dietary copper for animals (Goodman and Gilman, 1956).

Increased amounts of copper appearing in the sea are the result of the contamination of rivers by base-metal mines and by the spraying of copper algicides. Copper in small quantities is supposed to be lethal to plants but harmless to animals.

Some of the effects on fresh water vertebrates of increases in copper above trace amounts have been documented (Sprague, 1964 and Sprague and Ramsey, 1965) and the response of invertebrates to copper has been studied by Hubschmann (1967). The present study on the Winter Flounder has a two-fold purpose: to determine the histological and ultrastructural effects of varying concentrations of copper on a representative marine vertebrate, and to relate these findings to the medical knowledge of copper metabolism. Most of the accumulated knowledge on copper biochemistry comes from biomedical sources. This metal 
has come under close scrutiny concerning its action as an endogenous poison in Wilson's Disease, a disease that afflicts a small proportion of humans.

Emphasis is placed on the section of the experiment concerning very low concentrations of copper since this is the area least explored. The effects of lethal levels of various toxicants have received much attention, but perhaps sublethal levels affect the biosphere to a greater extent, since the subjects of such poisoning may become sick, adapt or respond in other ways, but not die.

There is certainly more sublethal pollution than lethal pollution and it is felt, by this author, to be important for pollution scientists working within a Fisheries framework to become aware of the histological, ultrastructural, and biochemical advances of medicine and of related sciences, since man and fish are really one.

The results of this study have been accepted for publication in the Journal of the Fisheries Research Board of Canada (Baker, 1969). 
MATERIALS AND METHODS

Medium and high levels of copper

Winter Flounder, Pseudopleuronectes americanus, were collected by otter-trawling in Passamaquoddy Bay, New Brunswick, in May 1967 and kept in running sea-water for an initial period of two weeks at $9.0^{\circ} \mathrm{C}$. The fish used in the experiments were three years old, as determined by counting otolith annulations.

Five fish were placed in each of four tanks containing 25 liters of sea-water with a constant water flow of 1 liter per minute. The temperature of the water was maintained at $10^{\circ} \mathrm{C}$. Copper was supplied in the form of copper sulphate and concentrations of $3200 \mu \mathrm{gm} / 1 \mathrm{Cu}, 1000 \mu \mathrm{gm} / 1 \mathrm{Cu}$, and $560 \mu \mathrm{gm} / \mathrm{I} \mathrm{Cu}$ were maintained in three of the tanks by dripping a solution of distilled water and copper sulphate into the tanks at a predetermined rate. The stock copper sulphate solutions were agitated with magnetic stirrers.

The fourth tank was kept free of exogenous copper and was maintained for control fish. The copper concentration was measured colorimetrically by the diethyldithiocarbamate method similar to that described in "Standard Methods" (APHA, 1960). Copper was found by this technique in concentrations of $\mu \mathrm{gm} / 1$ in the sea-water of the control tanks.

All the tanks were aerated. The $\mathrm{pH}$ of the water in the fish tanks remained at $8.0_{-}^{+} 0.1$, throughout the experiment. 
The fish were fed each day with frozen clams. Since only the control animals were feeding well, a fifth was set up as a starved control (Figure 19).

The fish were exposed to copper in the above way for 700 hours (Figure 19). Tissues for histological examination were taken from fish killed by decapitation just before "natural" death. Death was thought to be imminent as judged by typical neuromuscular disabilities. Some of the fish became increasingly irritable as the experiment proceeded, resulting in some cases in spasmodic movements severe enough to cause the fish to eject themselves out of the water. Finally the fish remained upside down and motionless on the bottom of the tank. When they were turned the right way up they slowly returned to their upside down position. When these symptoms were ignored the f'ish died, and they were considered unusable for microscopical examination. One such fish died in each of the experimental tanks and these were not used for histological purposes. Figure 19 shows the fate of each $f^{\prime}$ ish in each of the tanks; the circles marked with a cross represent a fish that died and was not examined histologically. None of the control fish died during the 700 hour experiment and none showed any sickness.

The following tissues were taken for histological examination: somatic musculature, gills, heart, stomach, duodenum, intestine, kidney, liver, eyes, brain and spleen. All were fixed in Bouin's fluid, embedded in $56^{\circ} \mathrm{C}$ wax, sectioned at $6-8 \mu$ and stained with haematoxylin and eosin. 
Low level of copper

Two year old fish collected by handlining were used in this experiment. Since they were smaller than three year old fish possible crowding effects in the tanks were minimized. The fish were kept in groups of six, in four tanks each containing 60 liters. Two of the tanks were maintained at a concentration of $180 \mu \mathrm{gm} / \mathrm{I} \mathrm{Cu}$ and two were maintained as control.

Fresh, live clams were used as tood and all $f^{\prime \prime} i$ sh fed well. The temperature of the tanks in this experiment was maintained at $10^{\circ} \mathrm{C}$.

The fish were exposed in the above way tor 300 hours (Figure 19). Tissues taken for histological examination were treated as in the previous experiment except that gill tissues for electron microscopical examination were fixed in $2 \%$ phosphatebuffered glutaraldehyde at $10^{\circ} \mathrm{C}$ for two hours, rinsed in phosphate butfer for 15 minutes, then post-fixed in osmium tetroxide. The tissues were then dehydrated by graded ethanol baths and embedded in Epon 812. After sectioning and staining with lead citrate (Reynolds, 1963), the specimens were examined in a Phillips 200 electron microscope or an R.C.A. $3 E$ electron microscope. 


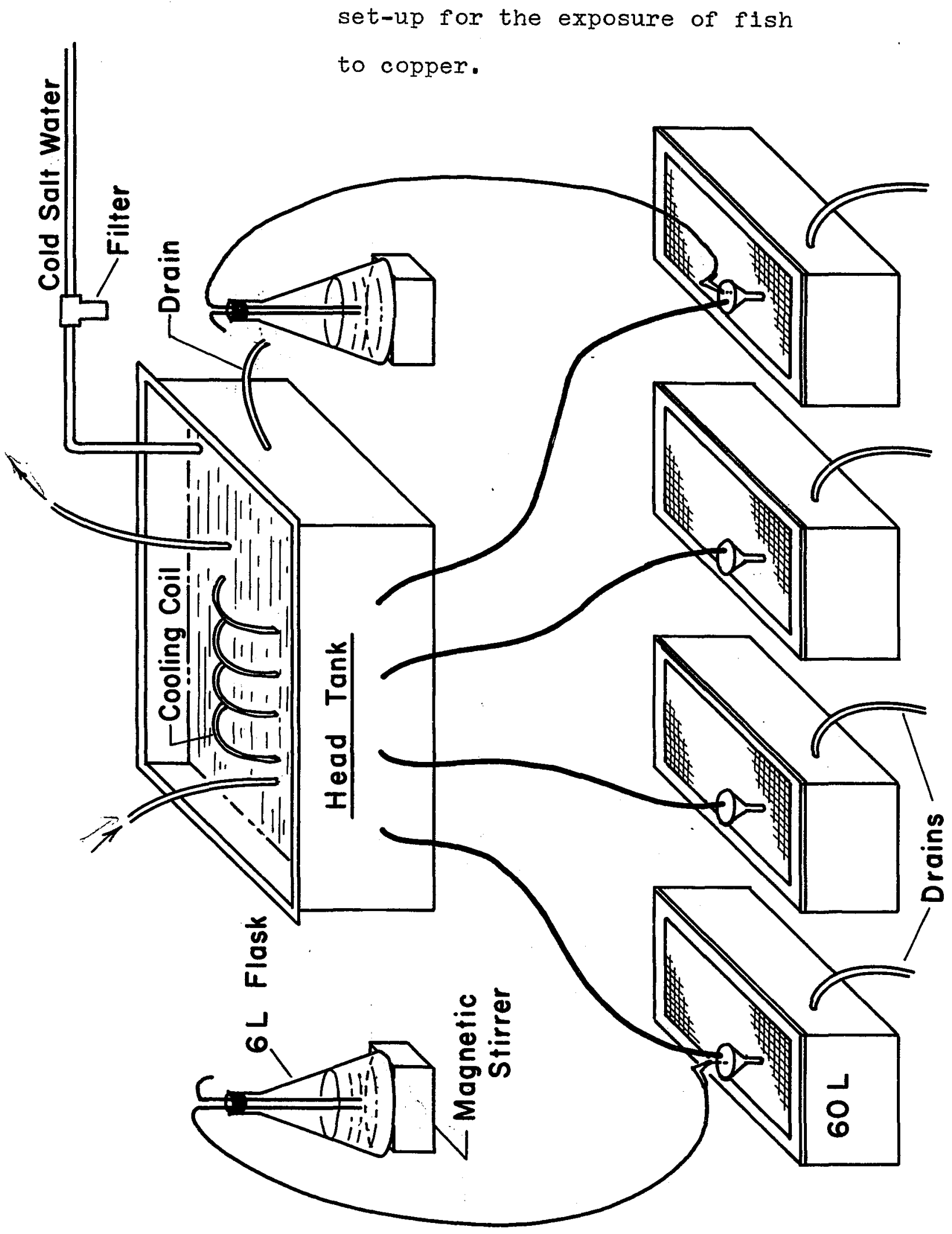


RESULTS

A few general remarks are in order before the detailed histological and electron microscopical observations are described.

Similar amounts of food were given to all the fish throughout the 700-hour experiment. Food that was not eaten within a fifteen minute period after feeding was promptly withdrawn from the tanks. Of possible importance is the fact that the high and medium doses of copper resulted in poor feeding habits. These fish made little or no attempt to eat, but the control fish ate well. There appeared to be no ditterence between the eating habits of the animals exposed to the low level of copper and those of the control f'ish.

Mucus secretion by the tish had a direct relationship to the amount of copper present in the water. Fish exposed to $3200 \mu \mathrm{gm} / 1$ of copper secreted so much mucus that it had to be cleared from the tank each day, while those exposed to $180 \mu \mathrm{gm} / 1$ of copper secreted only a little more mucus than did the control fish. The starved control tiish secreted least mucus of all and their tank was always clean.

Death of the fish by copper poisoning was preceded by severe neurological and muscular aberrations. The fish exposed to high and medium doses of copper were more irritable than the control. This irritability was manifested in great agitation whenever the tank cover was removed or when adjustments had to be made to water and toxicant flow. 
An attempt to reduce these agitated movements was made by covering the whole apparatus with black plastic and by approaching the tanks slowly and cautiously. As the fish approached death, these nervous disorders increased until the animals al ternately ejected themselves in the air or hung upside down in the water. If an animal that remained upside down was slowly and gently turned over, and if the gills still pumped and yet it did not make an attempt to swim, it was immediately sacrificed for histological purposes. If an animal was left in the tank after this experiment, it died a few hours later. One animal from each of the poisoned tanks from the first experiment died in such a way. A sixteen hour a day watch was kept on the tanks for the first experiment to reduce the number of such fatalities to a minimum. Fatalities are recorded in Figure 19 as crossed circles. 
Medium and high levels of copper

(Light microscope observations)

\section{Liver}

Figure 1 is a photomicrograph of a section of liver from a control fish. The central vein (cv) is prominent and several blood-filled sinusoids (s) leading directly to it separate the cords of hepatic tissue (ht).

$$
\text { Figure } 2 \text { is a photomicrograph of a similar area }
$$

from a fish exposed to $1000 \mu \mathrm{gm} / 1$ of copper. The cells making up the hepatic tissue surrounding the central vein have become filled with large fat droplets (arrows). Fat deposition of this type is called lobular fatty metamorphosis. The droplets of fat appear to be clear due to the histological processing which dissolves fat. Both $1000 \mu \mathrm{gm} / \mathrm{I}$ of copper and $3200 \mu \mathrm{gm} / \mathrm{I}$ of copper result in fat deposition while $560 \mu \mathrm{gm} / \mathrm{l}$ of copper does not alter the appearance of the liver from that of the control to any apparent extent. 
IIVER

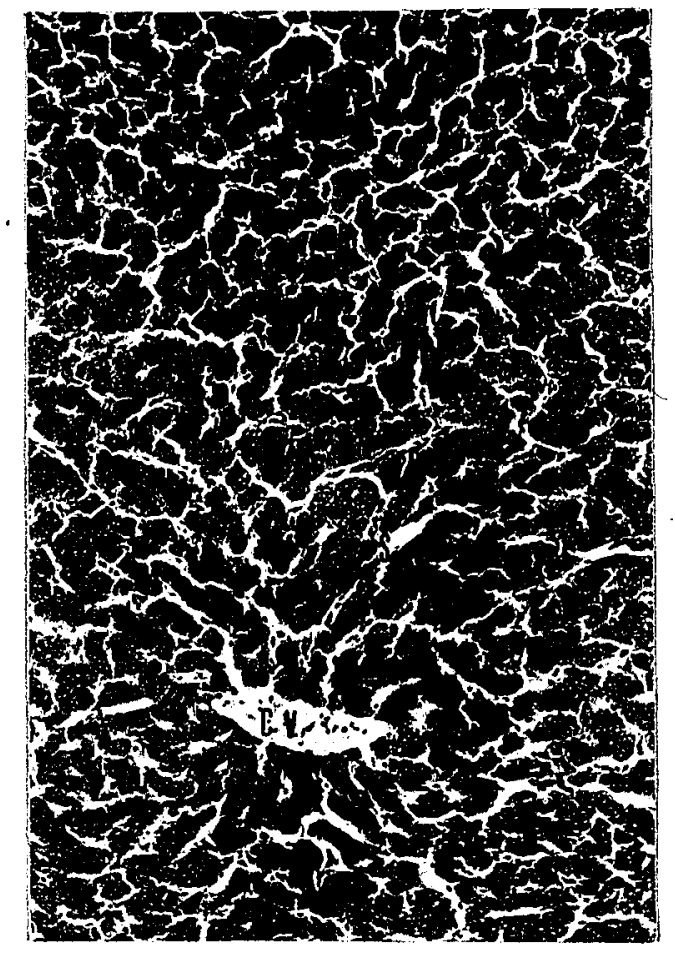

Figure 1

$280 \mathrm{X}$

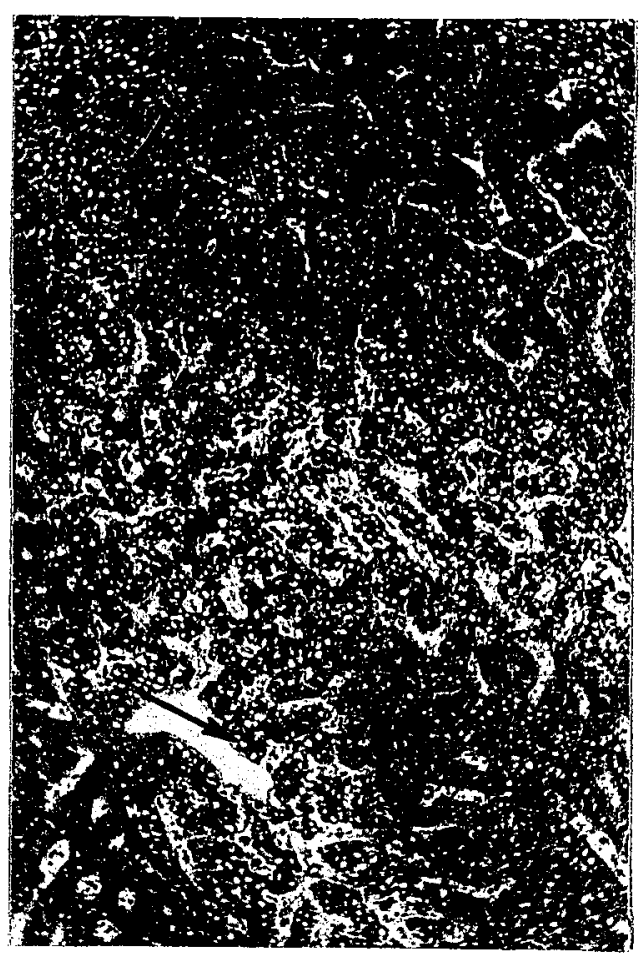

Figure 2

$280 \mathrm{X}$

Figure 1: control. The normal appearance of liver is shown in this photomicrograph. Hepatic tissue cells (ht), sinusoids (s), and the central vein (cv), are shown.

Figure 2: $1000 \mu \mathrm{gm} / \mathrm{I}$ of copper. Effects of copper on liver result in fat deposition within liver cells (arrow). 
$\underline{\text { Kidney }}$

Figure 3 illustrates the appearance of normal kidney tissue. The teleostean kidney is characterized by having the tubules surrounded by haemopoetic tissue. A glomerulus ( $g$ ) surrounded by embryonic red blood cells (arrows) is in the center of the photomicrograph. Several tubules ( $t$ ) are present. Figure 4 shows the effects of $3200 \mu \mathrm{gm} / 1$ of copper. The tubule cells are shrunken and have vacuolated cytoplasm (arrows). The haemopoetic tissue is necrotic (circle) and very much reduced in volume. The tubular Iumen may contain large clumps of dense material.

$1000 \mu \mathrm{gm} / \mathrm{l}$ of copper results in similar histopathological effects. Concentrations of copper at $560 \mu \mathrm{gm} / \mathrm{I}$ and below do not elicit these changes. 
KIDNEY

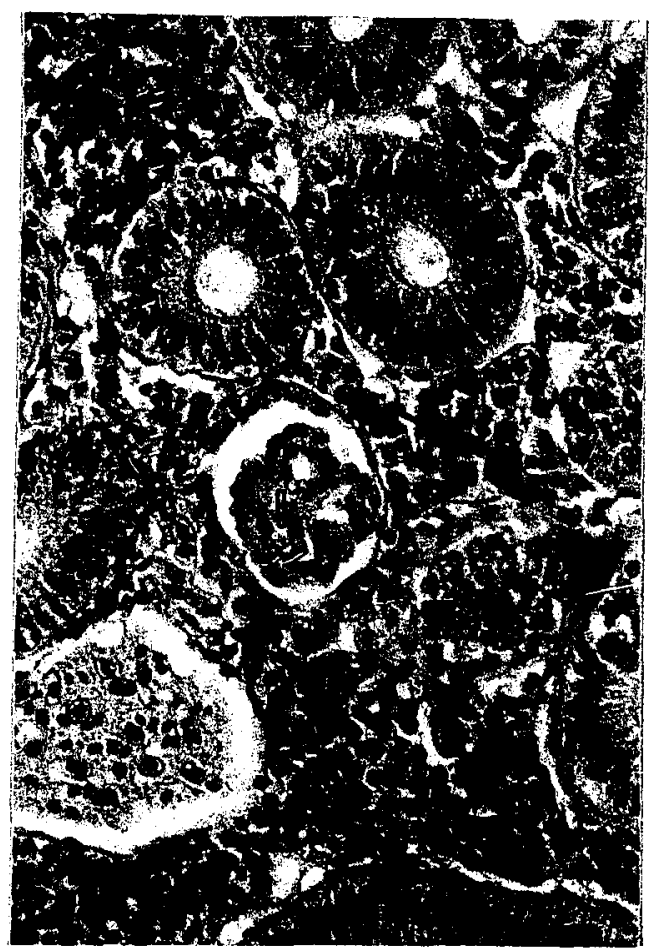

Figure 3

$1,00 \mathrm{X}$

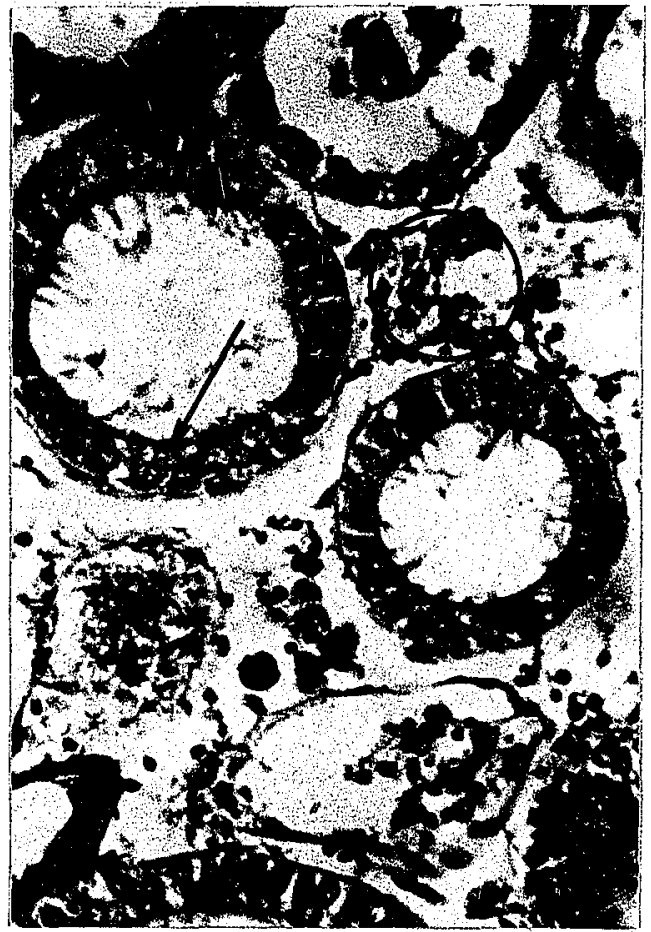

Figure 4

$1,100 \mathrm{X}$

Figure 3: control. Normal flounder kidney histology is shown in this photomicrograph. Glomerulus (g), kidney tubule ( $t$ ), peritubular red blood cells (arrows), are shown.

Figure $4: 3200 \mu \mathrm{gm} / 1$ of copper. The effects of high levels of copper are readily apparent: disintegration of tubule cells (arrow), necrosis and lack of red blood cells between the renal tubules (circle). 
Gills

Figure 5 shows the gill structure in a control animal. The lamellae (1) emerge on either side of the filament (f). The lamellar histology is similar to that described for other species (Newstead, 1967). Each lamella is formed of central pillar cells (arrow) that have arms which stretch out to touch those of adjacent pillar cells. The space between the pillar cells forms lacunae through which red blood cells flow. In the basi-lamellar (bl) region situated on the filarnent are chloride cells and at intervals along the layer of epithelial cells are numerous mucus cells (Figure 7). In normal epithelium there are very few chloride cells among the epithelial cells on the lamellae. The area circled is magnified in Figure 10 for greater detail.

Mucus cells can be distinguished from chloride cells by the fact that they are not as eosinophilic and thus remain paler when stained with eosin; they also tend to be spherical while chloride cells are flatter.

Figure 6 shows the gills of a fish exposed to 3200 $\mu \mathrm{gm} / 1$ of copper. There is al most complete epithelial cell destruction, with some fusing of adjacent lamellae. Chloride cells are the only cells that are still recognizable, apart from the red blood cells which can be found outside the lamellae (circle). The remains of the epithelial layer have become completely detached from the more central portion of each lamella. The basi-lamellar region is disintegrated (arrow). 
$1000 \mu \mathrm{gm} / 1$ of copper in the gills result in the epithelial layer lifting off from the remaining parts of the lamella; chloride cells are greatly enlarged, as are the mucus cells. In some cases, it appears that the apparent detachment of the epitinelium from the basement membrane is really a greatly expanded chloride cell, since the typical eosinophilic contents of the chloride cells are contained in the bubble formed by the epithelial detachment. Lamellae fuse together in some cases, while others become swollen with many red blood cells due to the presumable loss of the supporting function of the pillar cells. Epithelial cells often become so disintegrated that there is little cellular detail to be observed.

At $560 \mu \mathrm{gm} / 1$ of copper the epithelial layer of cells of the lamellae becomes reduced in size, but there is no detachment from the basenent membrane. Mucus cells are larger in size than those of the control specimens and chloride cells make their appearance along the epithelial layer. The chloride cells can be few or numerous and in some cases the epithelial layer may be made up entirely of chloride cells. 


\section{GILIS}

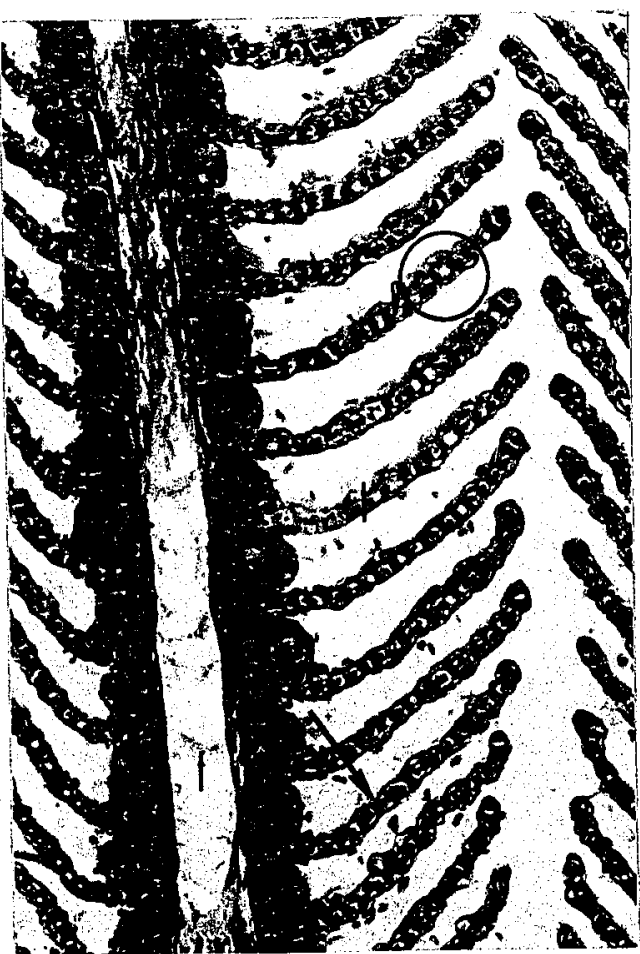

Figure 5

$450 x$

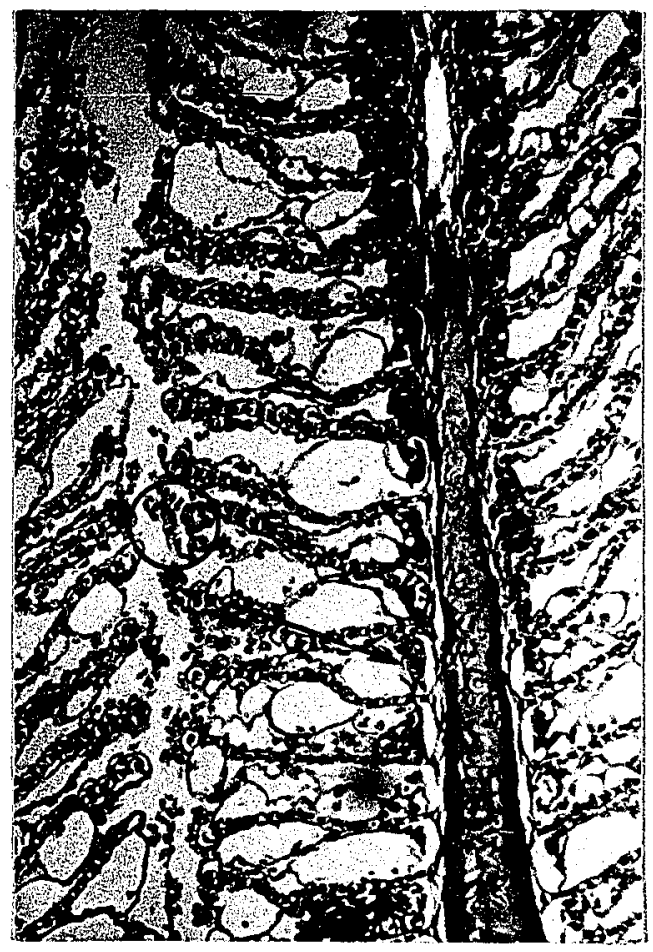

Figure 6

$380 x$

Figure 5: control. Part of a gill filament and several lamellae are shown in this photomicrograph. Filament $(f)$, lamellae (I), basi-lamellae region (bl), and a pillar cell (arrow). The circle around part of a lamella illustrates the area from which all the electron micrographs are taken.

Figure 6: $3200 \mu \mathrm{gm} / \mathrm{l}$ of copper. High levels of copper on the gill result in a reduced thickness of basi-lamellar region (arrow) and detachment of epithelium from lamellae resulting in a number of free red blood cells (circle). 
Low level of copper

(Light microscope observations)

\section{Gills}

Figure 7 shows the appearance and distribution of mucus cells (arrows) on normal gill lamellae. Note the appearance of the thick, well-formed, epithelial layer between the parallel lines.

Figure 8 is a photomicrograph of gills from a fish exposed to $180 \mu \mathrm{gm} / \mathrm{I}$ of copper. The epithelial layer between the parallel lines and elsewhere is much thinner and has a vacuolated appearance. Many of the blood lacunae appear empty (arrow) and the basi-lamellar region is very much reduced in thickness (arrow-head).

Figure 9 shows some of the chloride cells (arrows) that appear in fish gill lamella epithelium after exposure to $180 \mu \mathrm{gm} / \mathrm{I}$ of copper; mucus cells are absent. 


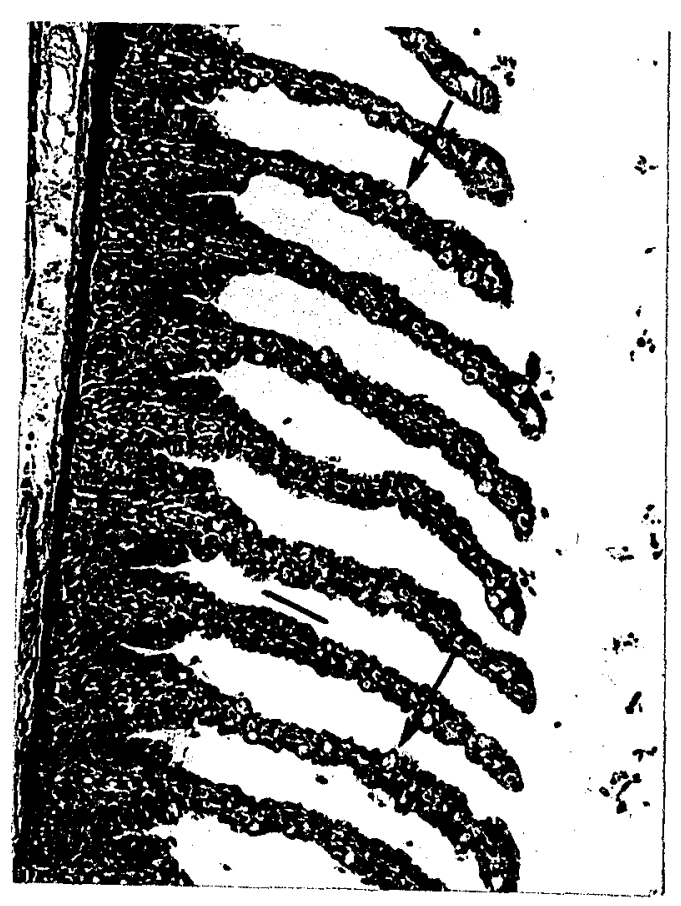

Figure 7: control $725 \mathrm{X}$

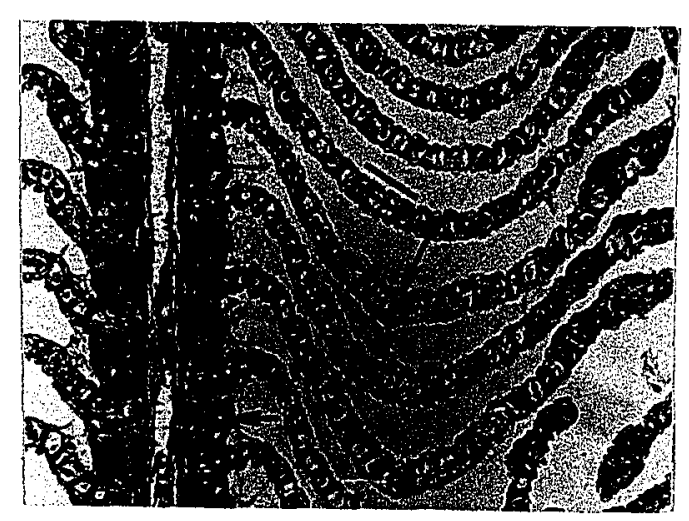

Figure 8: $180 \mathrm{ugm} / 1$ of copper $725 \mathrm{X}$

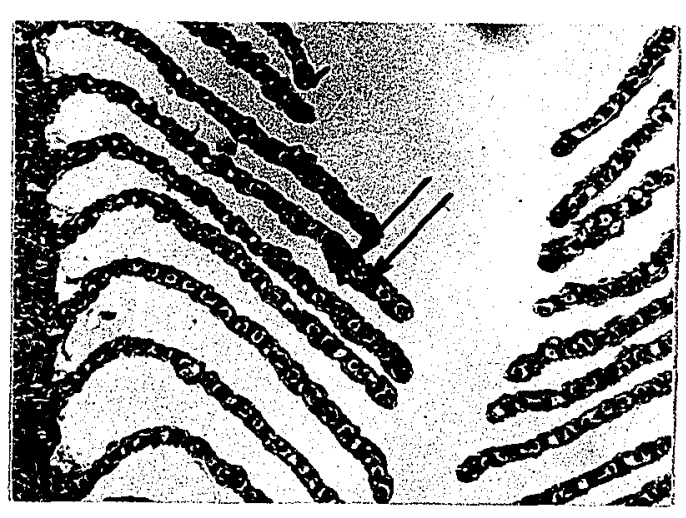

Figure 9: $180 \mathrm{ugm} / 1$ of copper $725 \mathrm{x}$

Figure 7: Normal epithelium (parallel lines), mucus cells (arrows). Figure 8: Reduced epithelium (parallel lines), empty lacunae (arrow), reduced basi-lamellar region (arrowhead). Figure 9: Appearance of chloride cells (arrows). 


\section{Normal gill ultrastructure}

Figure 10 shows a normal gill lamella of Winter Flounder from the same region circled in Figure 5. The ultrastructure of normal gill lamellae from another species has been described in some detail by Hughes and Grimstone, 1965. Each lamella has a crescent shape with one end higher than the other. The taller end faces the incurrent of water. The water flow on the outside of the gill lamella runs countercurrent to the blood flow on the inside of the gill lamellae.

Ali sections in this study were made across the lamellae, thus the red blood cells ( $r b c$ ) are either moving into or out of the electron micrographs. Around the blood cells are the pillar cells (pc), which form the structural support of the lamella. Between the pillar cell arms are the blood lacunae (arrows), i.e. spaces wi thin which the blood cells can move. External to the pillar cells are the two basement membranes $(\mathrm{bm})$, on each of which stands a single layer of cells. External to these layers lie the epithelial cells (e), the mucus cells (Figure 12) and the chloride cells (Figure 13). Frequently there is another kind of lacuna between the single layer and the epithelial layer, within which isolated cells (is) can be seen. External to the second lacunal system is the epithelial layer, which is one or two cells thick. The pillar cell has four arms $(p)$ and a centrally located nucleus $(n)$. There are a few mi tochondria within the homogeneous cytoplasm. There is little rough endoplasmic 
reticulum and few free ribosomes. The two arms on each side of the cell extend to those from an adjacent cell, forming a space between the cells. This space is the blood lacuna. The basement membrane is about $300 \AA$ in thickness and is continuous. It is intimately related to the pillar cells (Hughes and Grimstone, 1965). The single layer of cells external. to the basement membrane is very thin, usually thinner than the membrane itself. The cytoplasm of these cells contains a little endoplasmic reticulum and scattered mitochondria. The dark cell at the bottcm of this photograph is within the second lacunal space. The circle depicts the area shown in greater detail in the remaining micrographs of both normal and experimental animals. 
GILLS (GENERAL ULTRASTRUCTURE)

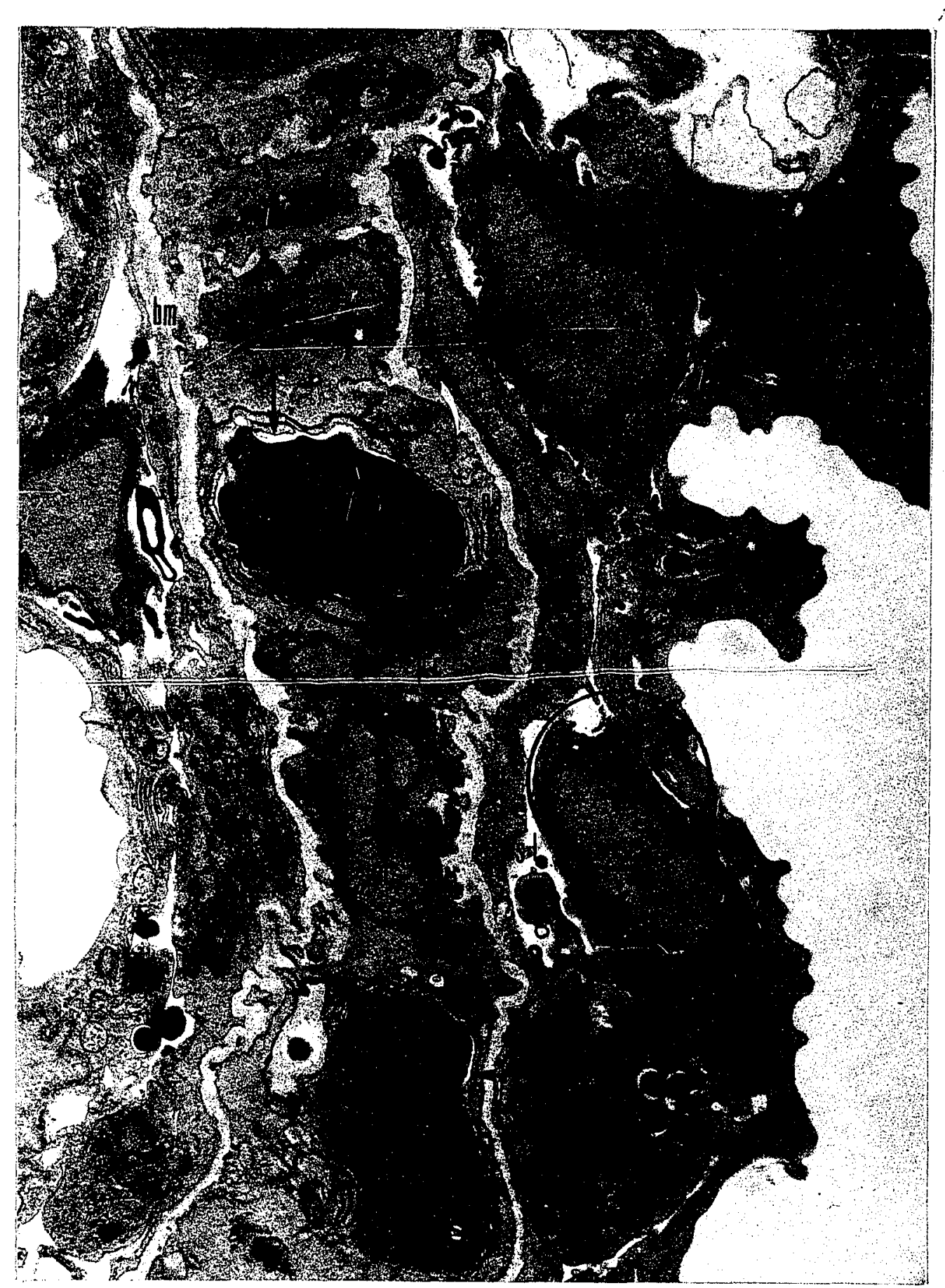

Figure $10.5,500 \mathrm{X}$

Figure 10: control. Ultrastructure of normal gill lamella. Pillar cell (pc), its nucleus ( $n)$, and arms ( $p$ ). Basement membrane (bm), epithelial cell (e), secondary lacuna (sl), isolated cell (is), and red blood cell (rbc). Blood lacunae (arrows). 
Drawing of the left half of

a gill lamella to make Fig. 10

easier to understand.

SEA

WATER

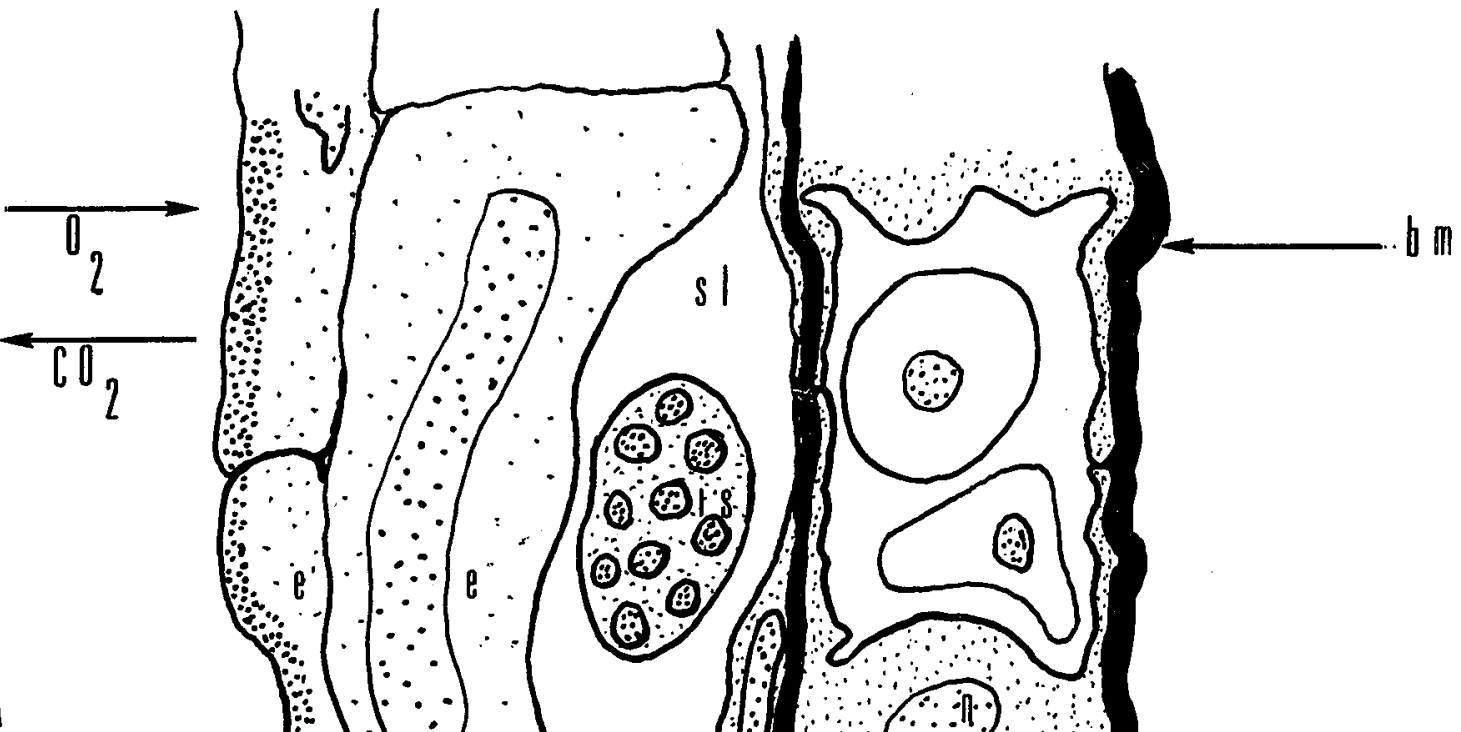


Drawing of the left half of
a gill lamella to make Fig. 10 easier to understand.

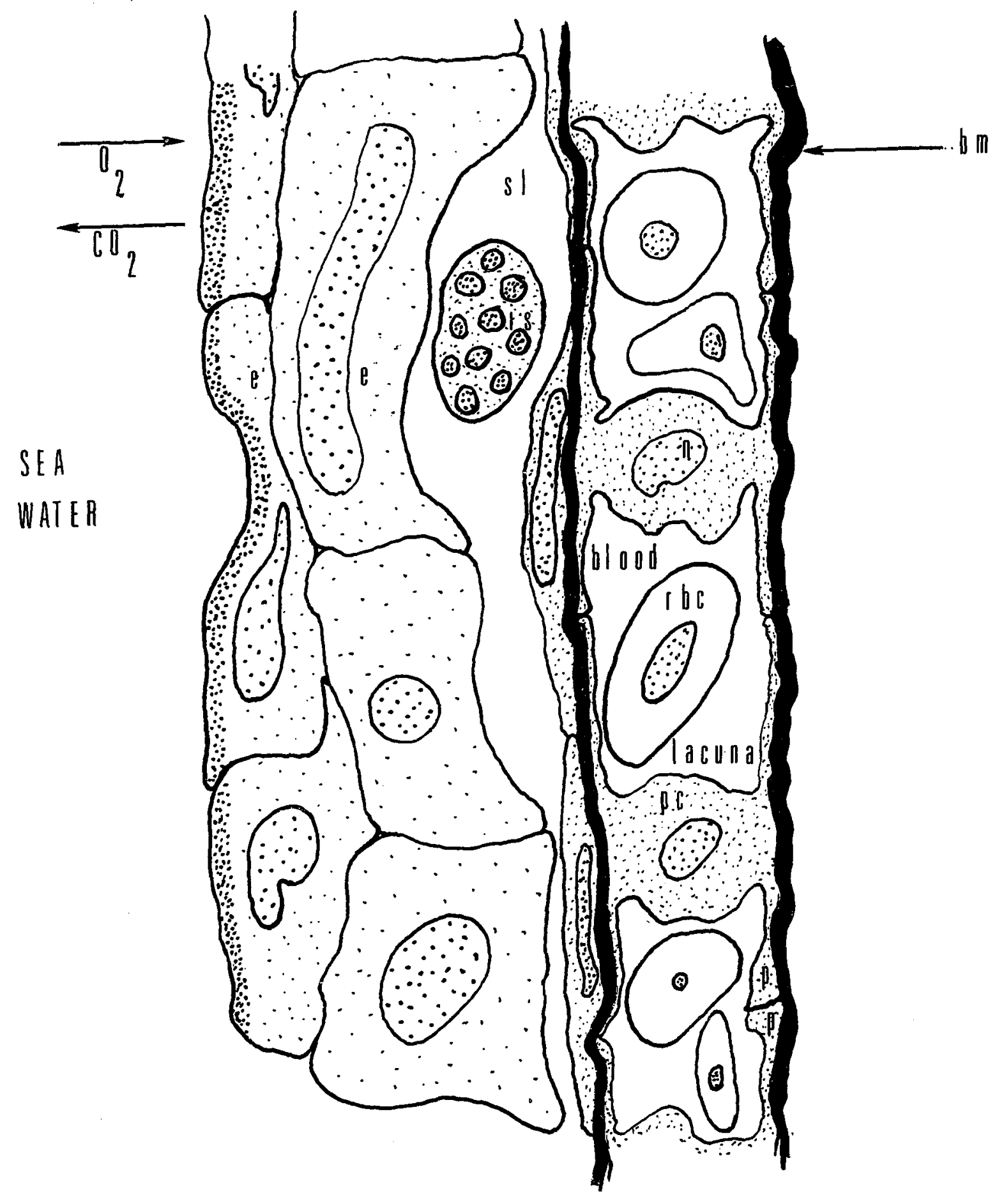


Gills (epithelial layer); control

Figure 11 shows the secondary lacunal space (sl), which contains a clear fluid in which float myel in-like bodies, free cells, membrane-bound vesicles and other structures. The epithelial cells tend to be long and flat and to have prominent nuclei $(n)$. There is little endoplasmic reticulum (arrow) and the Golgi apparatus is large although not shown in this particular micrograph.

The junction of one epithelial cell with another is complex, wi th many interfoldings of adjacent cell membranes. A few mitochondria (m) are present. Dense particles adhere to the surface of the epithelial cells. 


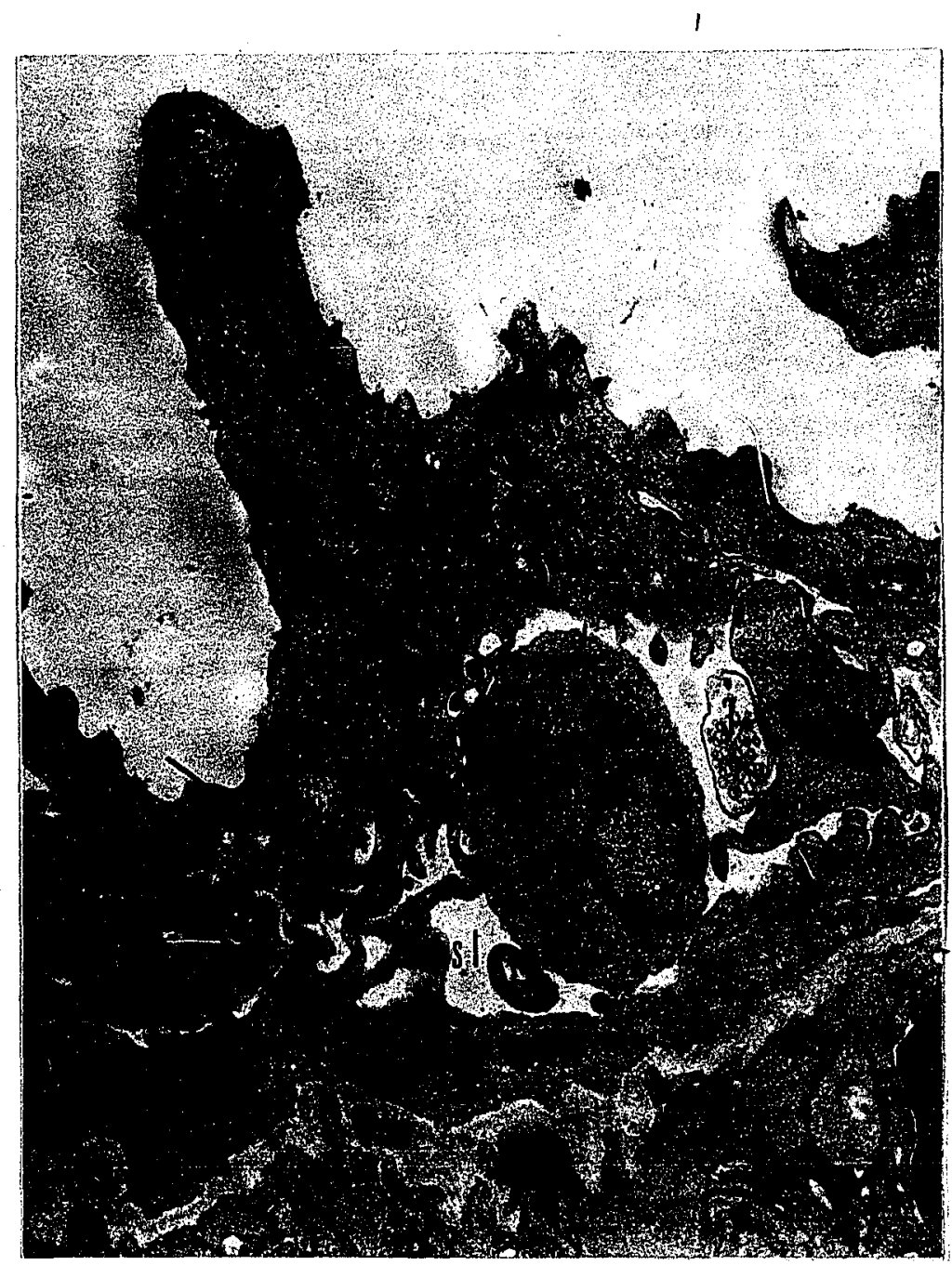

Figure 11

$$
10,000 \mathrm{x}
$$

Figure 1I: control. Details of the epithelial layer are shown in this electron micrograph: the nucleus of the epithelial cell ( $n)$, mitochondria (m), and rough endoplasmic reticulum (arrow), the secondary lacuna (sl), with various cell types $(1,2,3$, and 4$)$. 


\section{Gills (mucus cell); control}

Located on the gill lamellae in a similar position as the epithelial cells are the mucus cells (Figure 12). The mucus cell opens to the exterior by the apical aperture (arrow) which is surrounded by overlying extensions of the epithelial cells (e).

The mucus is contained by membrane-bound vesicles (mv) and each vesicle has a fine granular appearance. The nucleus ( $n$ ) is found in a basal position and is surrounded by an extensive endoplasmic reticulum (er). There are numerous free ribosomes in the cytoplasm and a few mitochondria (m). The Golgi apparatus ( $g$ ) is found at the base of the mucus vesicles.

There is a hair-like extension (arrowhead) of the apical homogeneous layer (parallel lines) of the epithelial. $\operatorname{cell}$. 


\section{GILLS (MUCUS CELL)}

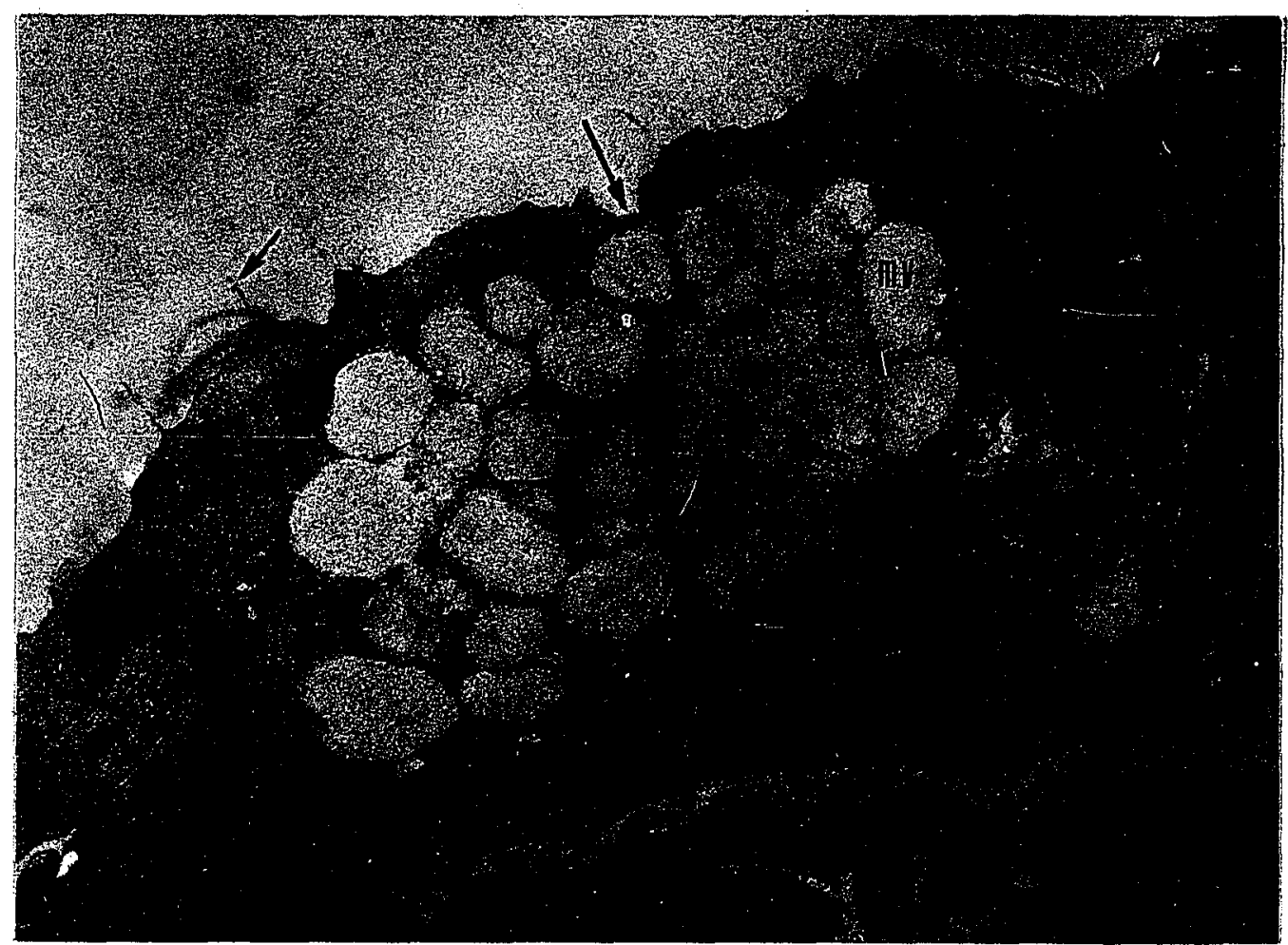

Figure 12

$$
10,500 \mathrm{X}
$$

Figure 12: control. Mucus cell nucleus $(n)$, mitochondria (m), Golgi (g), endoplasmic reticulum (er), and overlying epithelial cell (e); mucus vesicle (mv), and apical aperture (arrow); epithelial homogeneous layer (parallel lines) with a micro-hair (arrowhead). 
Gills (chloride cell); $180 \mu \mathrm{gm} / 1$ of copper

One of the most obvious changes in the gills due to low doses of copper is in the relationship of mucus cells to chloride cells; very few mucus cells are found while chloride cells are more common (see Figure 9). This suggests that one cell type can change into another type; that mucus secreting cells change to chloride secreting cells.

The section shown in Figure 13 is not through an apical aperture (similar in structure to the mucus cell), thus the overlying epithelial cell (e) appears to completely occlude the chloride cell.

Mitochondria (m) are numerous and there are a few free ribosomes (arrow). The dark granules adhering to the external membrane of the epithelial cell are similar to those found wi thin the mitochondria (arrowheads). Intermitochondrial space is occupied by the typical smooth endoplasmic reticulum or ergastoplasmic network. 


\section{GILLS (CHLORIDE CELI)}

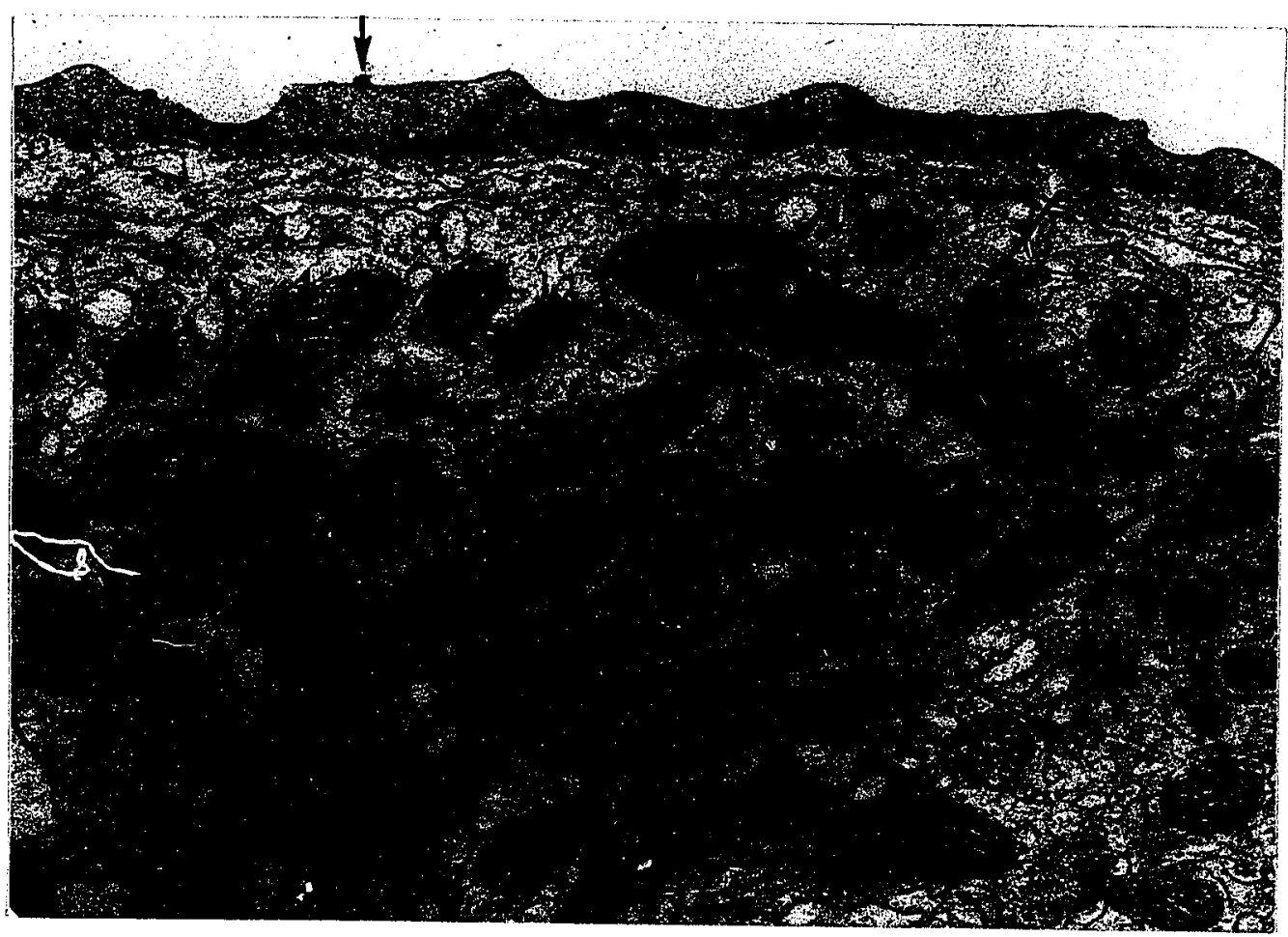

Figure 13

$29,000 x$

Figure 13: $180 \mu \mathrm{gm} / \mathrm{l}$ of copper. Part of a chloride cell. The cytoplasm consists to a large extent of mitochondria $(m)$, with space in between taken up by smooth endoplasmic reticulum. There are some free ribosomes (arrow). Arrowheads indicate granules within mitochondria and affixed to the external surface of the overlying epithelial cell (e). 
Gills (myelin-like bodies); $180 \mu \mathrm{gm} / 1$ of copper

Figure 14 shows portions of two epithelial cells ( $I$ and II) lying juxtaposed to the basement membrane (bm). Red blood cells ( $\mathrm{rbc}$ ) can be seen within the lacuna (1). No secondary lacunal space can be seen in this section. The outermost epithelial celI (II) contains numerous bodies that appear after exposure to $180 \mu \mathrm{gm} / 1$ of copper. These bodies consist of concentric membranous rings and appear to be myelin bodies in various stages of development (numbers). 
GILLS (MYELIN BODIES)

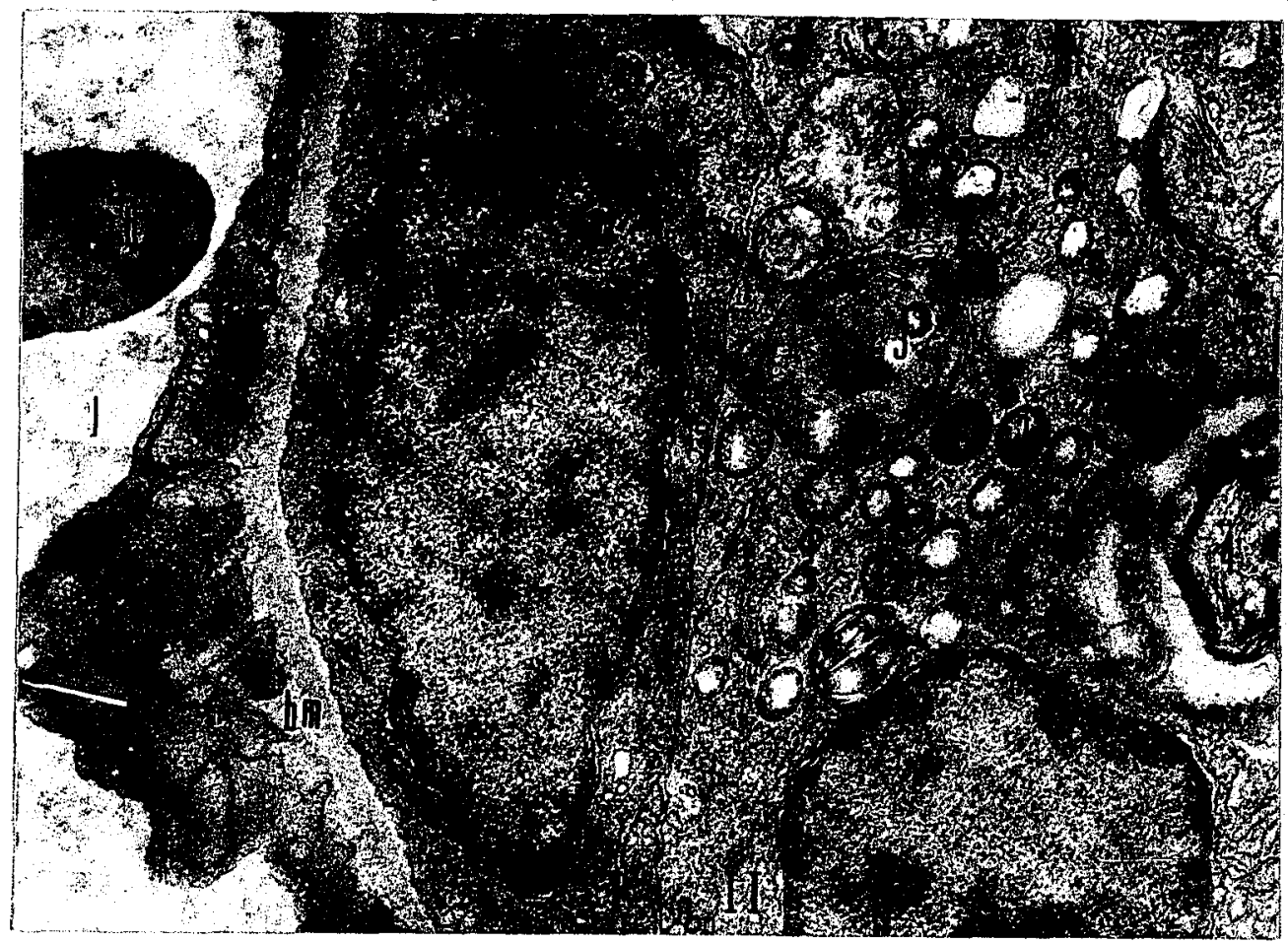

Figure 14

$20,000 \mathrm{x}$

Figure 14: $180 \mu \mathrm{gm} / 1$ of copper. Formation of myelin-like bodies wi thin epithelial cell ( $1,2,3$, and 4). Lacuna (1), red blood cell ( $r b c$ ), and basement membrane (bm). Two epithelial cells ( $I$ and II). 
Gills (Autophagosomes); $180 \mu \mathrm{gm} / \mathrm{l}$ of copper

Figure 15. Exposure to copper appears to result in the formation of autophagosomes (arrows) within epithelial cells. Autophagosomes are membrane-bound cellular bodies that contain enzymes that degrade cellular material. Elements of the rough endoplasmic reticulum have been absorbed by the autophagosomes where they will be degraded. Autophagosomes eventually result in the destruction of the cell that produces them. 


\section{GILLS (AUTOPHAGOSOMES)}

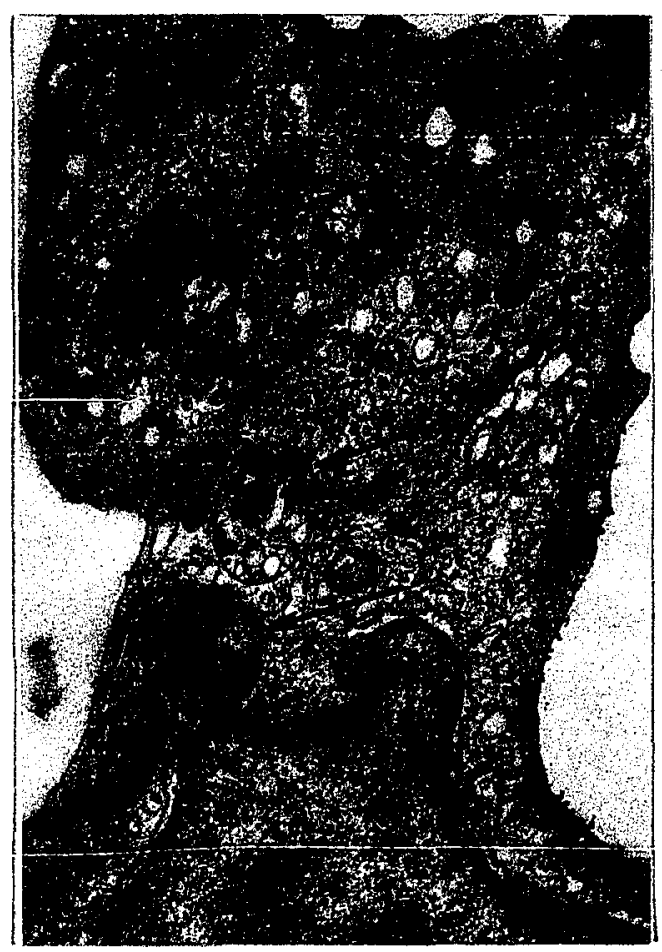

Figure 15

$$
21,000 \mathrm{X}
$$

Figure 15: $180 \mu \mathrm{gm} / 1$ of copper. Autophagosomes (arrows). 
()

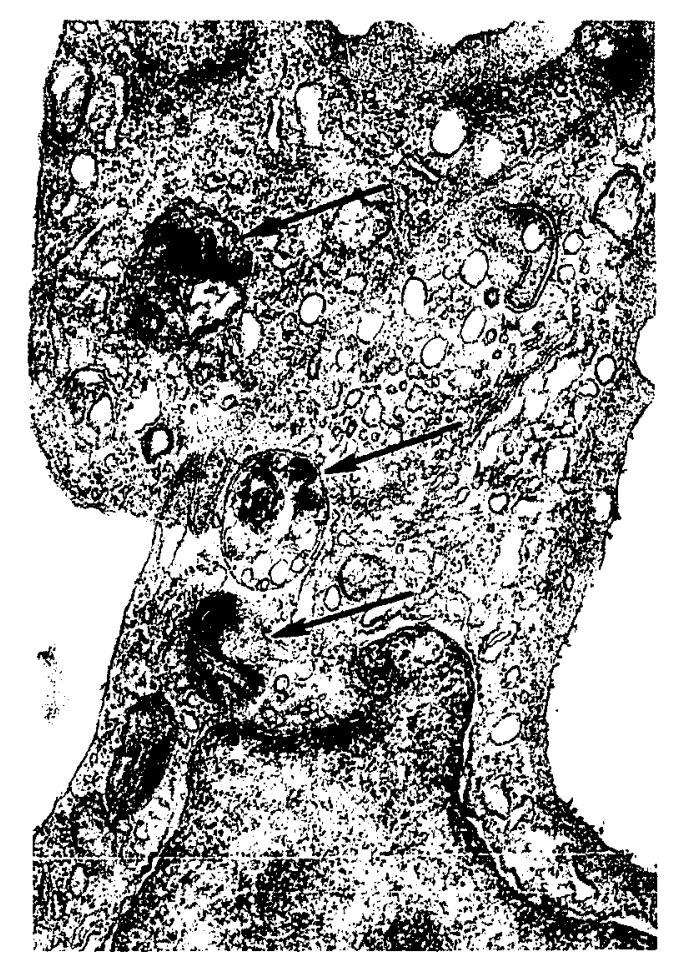

$$
\begin{gathered}
\text { Figure } 15 \\
21,000 \mathrm{X}
\end{gathered}
$$

Figure 15: $180 \mu$ grn/l of copper. Autophagosomes (arrows). 
Gills (Vesicles); $180 \mu \mathrm{gm} / 1$ of copper

Figure 16 shows a vesicular system that appears in the apical region of the epithelial cell from a copper-exposed fish gill. Some of the vesicles have small membrane-bound spherules contained within them and some are empty. The arrowhead points to an area where the contents of a vesicle appear to fuse with the homogeneous layer. This vesicular system seems to be related to the homogeneous layer (parallel lines). 


\section{GILLS (VESICLES)}

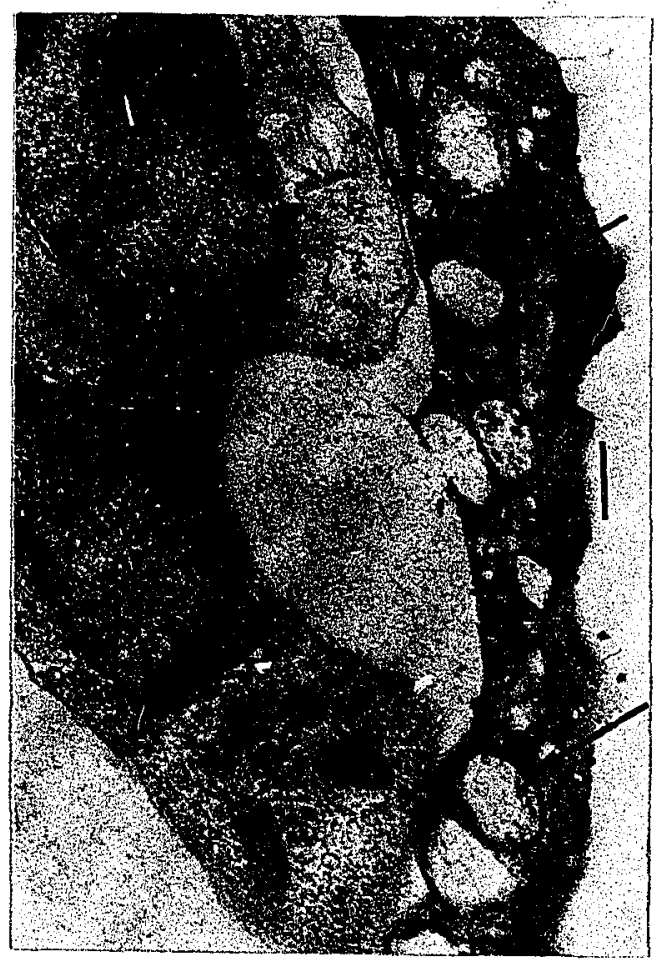

Figare 16

$21,000 x$

Figure 16: $180 \mu \mathrm{gm} / 1$ of copper. A vesicular system (arrows) in the homogeneous layer (parallel lines). 
(3)

(2)

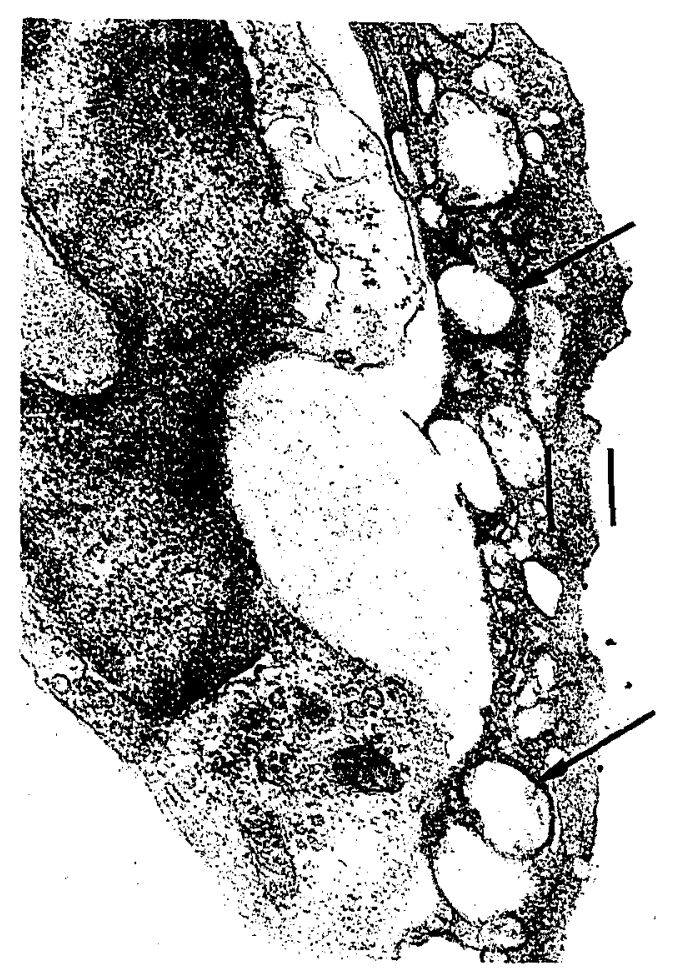

Figure 16

$21,000 \mathrm{X}$

Figure 16: $180 \mu \mathrm{grn} / 1$ of copper. A vesicular system (arrows) in the homogeneous layer (parallel lines). 


\section{Gills (Particulate Matter): $180 \mu \mathrm{gm} / 1$ of copper}

Figure 17 illustrates the great increase of adhering particulate matter (arrow) on the outer epithelial cell membrane in the gills of fi sh subjected to a low dose of copper. Compare with similar area from Figure 11. There is very little of the homogeneous layer in these cells (parallel lines). The secondary lacunal space can be seen (sl) with an interconnecting channel (c). 


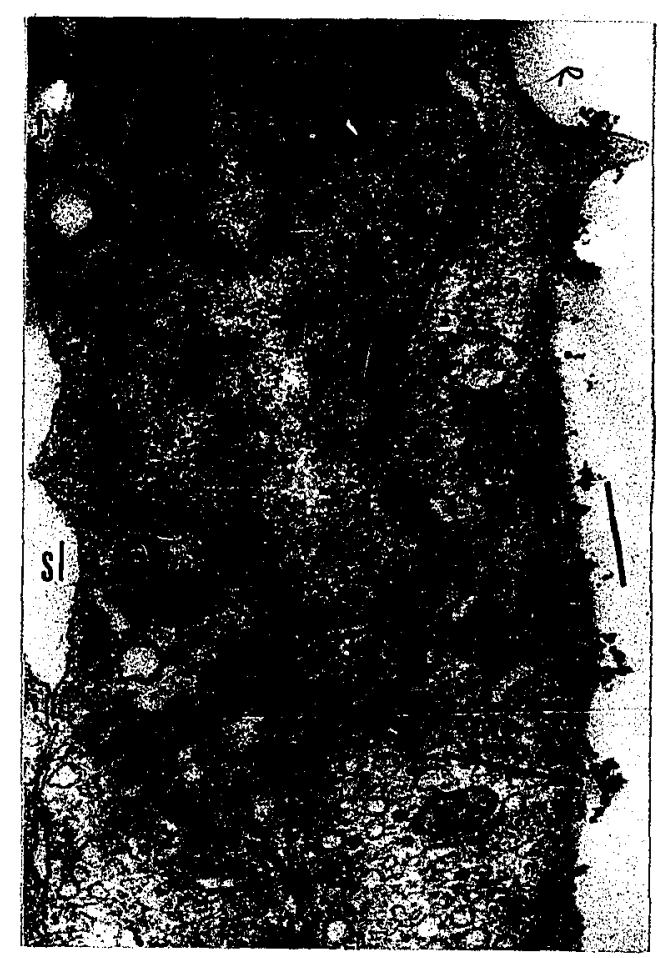

Figure 17

$$
21,000 \mathrm{X}
$$

Figure 17: $180 \mu \mathrm{gm} / 1$ of copper. An increase above the normal amount, of particulate matter, can be seen adhering to the external membrane (arrow). Note the reduced homogeneous layer (parallel lines), and the secondary lacuna (sl) wi th interconnecting channel (c). 


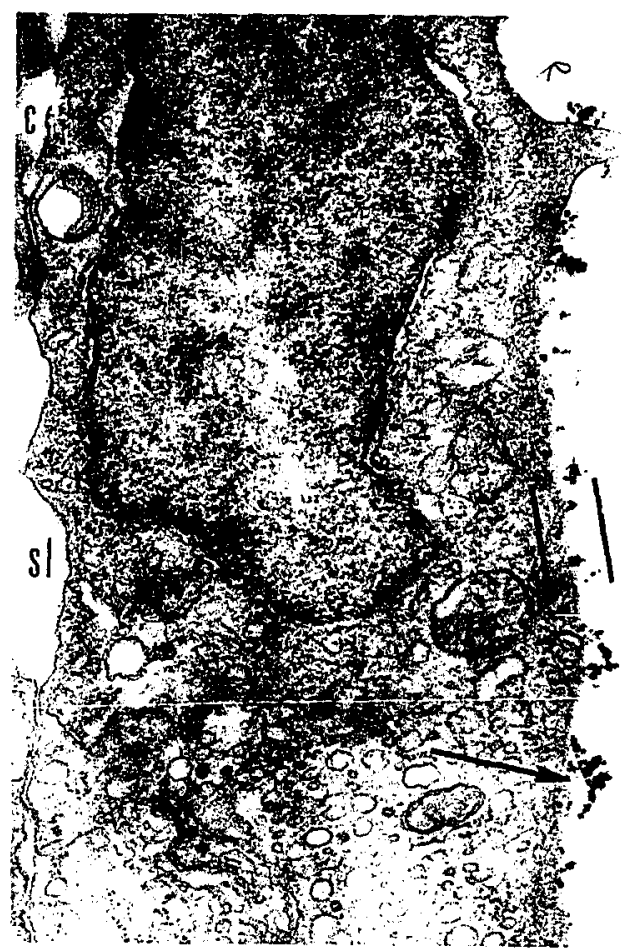

Figure 17

$21,000 X$

Figure 17: $180 \mu \mathrm{gm} / \mathrm{l}$ of copper. An increase above the normal amount, of particulate matter, can be seen adhering to the external membrane (arrow). Note the reduced homogeneous layer (parallel lines), and the secondary lacuna (sl) wi th interconnecting channel. (c). 
Gills (Vacuoles): $180 \mu \mathrm{gm} / \mathrm{l}$ of copper

Figure 18 shows the development of an extensive vacuolar system (vs) in the basal regions of the epithelial cell. This system seems to be membrane-bound (arrow). The homogeneous layer is reduced (parallel lines). Compare this region with that in Figure 12, which shows a similar region of a control specimen. When the difference in magnification is taken into account the reduction in thickness of the homogeneous layer due to low levels of copper is about one quarter of the normal thickness. 


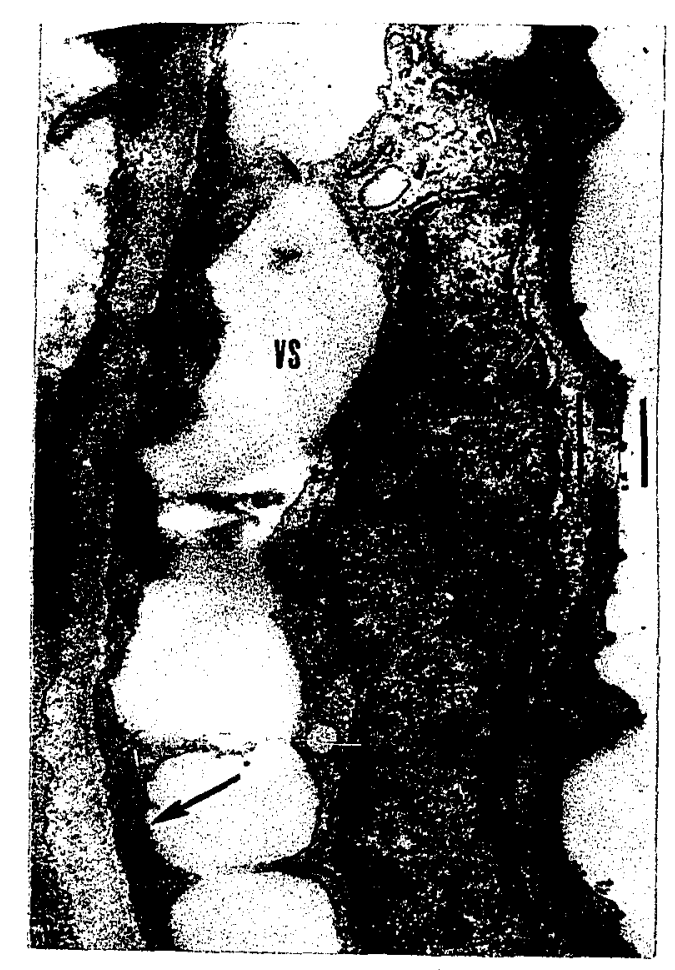

Figure 18

$$
21,000 x
$$

Figure 18: $180 \mu \mathrm{gm} / 1$ of copper. Vacuoles (vs), sur rounding membrane (arrow), and homogeneous layer (parallel lines). 
FE D

STARVED

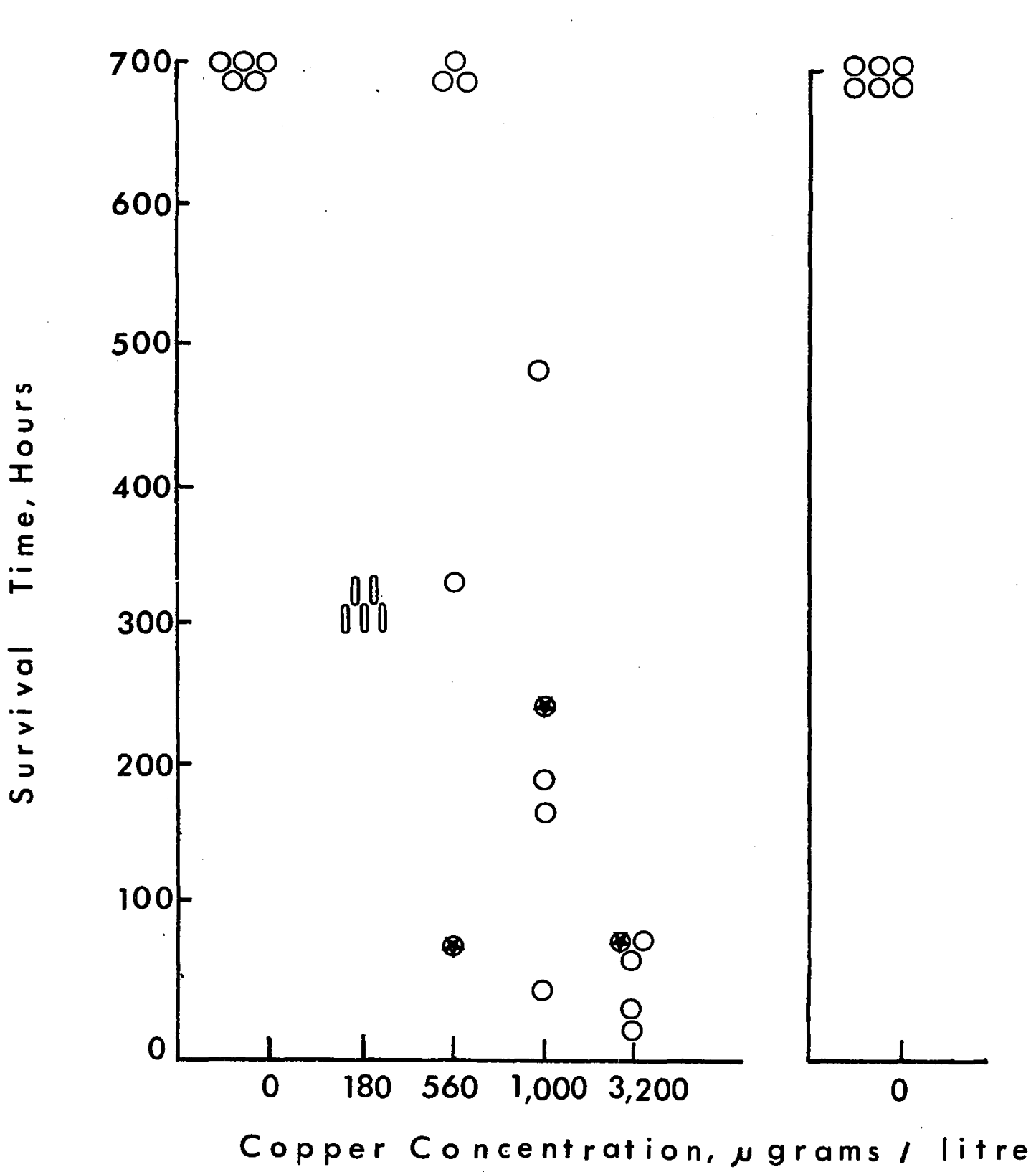

Figure I9: Fate of each fish in the experiments. The circles marked with a cross represent fish that died and were not examined for fear that natural postmortem changes might complicate changes due to copper poisoning. 


\section{DISCUSSION}

The use of histopathological techniques to investigate pollution effects is increasing. Some pollution scientists, following the lead of medical pathologists who have used these techniques for a much longer time and have accumulated much data on cellular response to various toxicants, are beginning to relate the amount of cell damage in organisms to the concentration of a pollutant and/or the synergistic effects of more than one toxicant (Brown et al., 1968, Crandell, C. A. and C. J. Goodnight, 1963).

An attempt has been made in this thesis to determine the histological effects of levels of copper that exist in nature as a result of man's activities by experimentally exposing a representative animal to various levels of copper emphasizing the sublethal level, since sublethal pollution is more widespread and is less obvious than lethal pollution. Copper is found normally in sea-water at very low levels in the order of $3 \mu \mathrm{gm} / 1-20 \mu \mathrm{gm} / 1$ (Atkins, 1953 and Chow and Thompson, 1954). In copper-polluted sea-water the concentration may reach over $300 \mu \mathrm{gm} / \mathrm{I}$ (Fujiya, 1960).

A toxic agent may be exogenous or may be produced by the organism itself as a result of deficient metabolic cycles. It is possible that the data accumulated by medical practitioners on pathological metabolism may be relevant to pollution studies of the histopathological type which concern only exogenous toxicants. Copper, as is the case with most heavy metals, is 
an essential part of many animals' intake, since this metal is involved in the complex molecular structure of enzymes. However, in larger than trace amounts it is a poison. Therefore before discussing copper as a specific pollutant in this study on Winter Flounder, a review of the medical knowledge of copper metabolism will be useful.

In normal mammalian physiology, copper, found in greatest amounts in the liver, brain kidney and haemopoetic tissue, is involved in many processes. Dietary copper is absorbed from the upper portion of the small intestine and is bound in the liver to an $\alpha$-globulin, producing a complex called ceruloplasmin. Copper is excreted in the faeces; urine and bile and it is intimately involved in normal haematopoesis since it is essential for the absorption of iron from the intestines and so controls the amount of iron available for haemoglobin synthesis (Goodman and Gilman, 1956).

Both an excess and a deficiency of copper cause pathological results in animals. Sheep that graze on a copper deficient pasture have poor haemoglobin levels and are anaemic (Comar and Bromer, 1962).

In human patients, the chronic effects of excess copper have been studied within the framework of Wilson's disease (Peisach et al., 1967). This disease is the result of an inborn error of metabolism, inherited in a recessive manner, which causes a toxic increase in body copper levels resulting, after a few years, in hepatic necrosis, haemolytic anaemia, 
and deposition of copper within the cornea in the form of a "Kayser-Fleischer" ring.

Wilson's disease itself results in chronic excess of copper not because of increased intake but because the liver fails to bind the cupric ion to the $\propto$-globulin. This failure results in a drop in the ceruloplasmin level which is the main clinical indication of the disease. Thus the copper is not excreted and is free to be carried about the body. This excess copper accumulates in the brain, liver, kidney, haemopoetic tissue and cornea. Enzyme systems then become involved, especially membrane ATP-ase (Peters, 1967) and the lipoic acid pyruvate system, resulting in cirrhosis of the liver, death of brain neurones, necrosis of kidney. tubules and the formation of Kayser-Fleischer rings. Copper interference with membrane ATP-ase also results in uncoordinated limb action and jerky, spontaneous movements. Copper also attacks various renal enzymes that mediate the resorption of several compounds. Haemolysis, a distinctive feature of Wilson's disease, could be caused by the interaction between copper and membrane ATP-ase, with the resulting breakdown of the sodium pump. Symptoms arising from the severe neurological disorders observed in Wilson's disease include jerky, spontaneous movements and possibly schizophrenia. Angel et al., (1957) reported that copper levels are high in schizophrenic patients but there is some controversy over this finding (Comar and Bromer, 1962). 
It is of note that on exposure to medium and high levels of copper the behaviour of the fish, i.e. jerky, uncoordinated, spontaneous movements, is similar to the symptoms of Wilson's disease in man. Although the typical brain lesions found in humans with Wilson's disease were not apparent in the brains of the $f$ ish, it is possible that their jerky, uncoordinated spontaneous movements resulted from the action of copper on their central nervous systems. The flounders in this study were exposed to copper for a maximum of 700 hours only, and humans with Wilson's disease exhibit apparent brain lesions a number of years after the onset of the disease. High levels of copper produce similar results in a variety of subjects. Peters (1967) reported that application of copper to the brain of pigeons produced serious convulsions. Vogel (1959) has shown that goldfish subjected to $1000 \mu \mathrm{gm} / 1$ doses of copper presented severe neurotoxic and nephrotoxic effects. Much of the research accomplished to date on the effects of heavy metals on aquatic organisms is biased towards determining the le thal limits for a particular toxicant. Few studies have been made to determine the effects of low doses of a toxicant and little is known about the physiological responses of fish to such concentrations. Hubschmann (1967) has discussed the inhibitory effects of copper on the respiratory enzymes of crayfish and copper has been shown by Fairbanks (1967) to cause haemolytic anaemia by inhibiting exythrocytic glycolysis, denaturing haemoglobin and oxidizing glutathione. 
Verity (1967) demonstrated that copper induces increased the specific activity of three lysosomal hydrolases and of several mitochondrial enzymes.

The overall observations suggest that copper induces haemolytic anaemia in fish as the primary lesion. This is supported by the fact that the haemopoetic tissue in the kidney of the Winter Flounder undergoes necrosis. Fatty metamorphosis of the liver and renal necrosis are assumed to be secondary lesions due to the probably anoxic state of the organism. In the eyes of the flounders no Kayser-Fleischer ring was found, probably due to the relatively short time that the fish were exposed to copper. Human patients suffering from Wilson's disease are not examined clinically until several years after the onset of the disease, giving the copper a much longer time to accumulate within the cornea.

It is difficult to tell whether the changes in the gill lamellae of the flounders as determined by light microscopy and electron microscopy are secondary or primary effects. Copper may be absorbed by the gill epithelium and may act primarily on the cell enzymes resulting in the formation of lysosomes, vacuoles and vesicles. The apical homogeneous layer of the epithelial cells may be a protective device and its reduction in size observed by electron microscopy may enable copper to enter these cells via this route instead of, or as well as, via the blood. The particulate matter that is normally present on the epithelial cell surface (Figure 12) occurs more 
extensively in animals that have been exposed to low levels of copper (Figure 17). It is possible that the copper acts as a coagulant on the mucus secreted by the cells within the epithelial layer and forms the dense particulate matter. It is not known whether increased particulate matter affects the oxygen/carbon dioxide exchange through the epithelial cells. Normal chloride cells from Fundulus heteroclitus have been studied by Kessel and Beams (1962) and Philpott and Copeland (1963) and are similar to those that appear in the gill lamellae of Pseudopleuronectes americanus exposed to low doses of copper. Munshi (1964) has suggested that the mucus cells of euryhaline fish can secrete either mucus or chloride ions; also that the mucus cells of fresh water fish can become functionally chloride-excreting cells when the fish are exposed to hypertonic solutions.

Chloride cells in the Winter Flounder are normally found only in the basi-lamellar region while mucus cells are mainly on the lamellae. After exposure to a low dose of copper, the number of mucus cells on the lamellae was reduced and chloride cells were found instead. If the copper-induced chloride cells were originally mucus cells, as seems to be the case, how and why do these transformations occur? Is it possible that these chloride cells excrete copper ions instead of chloride ions? Are there perhaps latent ion-excreting cells within the epithelium that only come into action when the medium requires it? 
Effects of lethal and sub-lethal levels of copper on the Winter Flounder, Pseudopleuronectes americanus were studied using routine pathological techniques and electron microscopical analysis.

Lethal levels of copper resulted in:

1. Lobular fatty metamorphosis in the liver.

2. Necrosis of the renal tubules.

3. Necrosis of the haemopoetic tissue.

4. Various changes in the gill lamellar structure, the most obvious being delamination of the epithelial 'layer.

Sub-lethal levels of copper resulted in many changes to gill architecture:

1. Reduction in thickness of the basi-lamellar cells.

2. Reduction in thickness of the epithelial layers.

3. Reduction in number of mucus cells in the lamellae.

4. Appearance of chloride cells in the lamellae.

5. Appearance of autophagosomes within gill lamellar epithelial cells.

6. Appearance of an extensive vacuolar system within gill. lamellar epithelial cells.

7. Appearance of vesicles under the apical homogeneous layer of gill lamellar epithelial cells. 
8. Appearance of myelin bodies within the cytoplasm of gill lamellar epithelial cells.

9. Reduction in thickness of the apical homogeneous layer of gill lamellar epithelial cells.

10. An increase in particulate matter adhering to the external membrane of the gill lamellar epithelial cells.

The behaviour of fish exposed to copper has been compared to the behaviour of humans suffering from Wilson's disease. Knowledge of copper metabolism from the medical field has been used to explain the toxic action of copper on the Winter Flounder. Possible points of entry of the copper into the fish have been discussed. The possibility that chloride excreting cells can also excrete other potentially toxic ions is suggested. 


\section{ACKNOWLEDGEMENTS}

I would like to thank the following people for their help and encouragement during this study.

Dr. Maxwell Dunbar who in the beginning agreed to my studying an aspect of marine pollution.

Dr. John Sprague for suggesting the project and for letting me use all the facilities of his laboratory in St. Andrews, N.B.

Dr. T. Carefoot who encouraged and hel ped this project through all its aspects.

Dr. M. Burt for letting me use his electron microscope at the University of New Brunswick.

Dr. H. Sheldon, Pathological Institute, McGill, for encouraging the preparation of this manuscript for publication and for letting me use his electron microscope.

Mr. V. Carsen for analysing water samples to determine concentrations of copper.

The Fisheries Research Board of Canada and the National Research Council of Canada both provided funds for this study. 
REFERENCES CITED

Angel, C., B. E. Leach, S. Martens, M. Cohen and Heath. 1957. Serum oxidation tests in schizophrenic and normal subjects. A.M.A. Arch. Neurol. Psychiat., 78: 500.

Atkins, W. R. G. 1963. The seasonal variation in the copper content of sea water. J. Mar. Biol. Ass., U.K. 31: 493 .

Baker, Jeremy T. P. 1969. Histological and electron microscopical observations on copper poisoning in the winter flounder (Pseudopleuronectes americanus).

Brown, V. M., U. V. Mitrovic and G. T. C. Stark. 1968. Effects of chronic exposure to zinc on toxicity of a mixture of detergent and zinc. Water Res., $2(4)$ : 255 .

Chow, T. J. and T. G. Thompson. 1952. The determination and distribution of copper in sea water. Part I. The spectrophotometric determination of copper in sea water. J. Mar. Res. 11: 124.

Chow, T. J. and T. G. Thompson. 1954. Seasonal variation in the concentration of copper in the surface water of San Juan Channel, Washington. J. Mar. Res. 13: 233.

Comar, C. L. and F. Bromer. 1962. Mineral Metabolism, Vol. 2, Pt. B: 371. Washington: Academic Press.

Crandall, C. A. and C. J. Goodnight. 1963. The effects of several toxicants to the common guppy, Lebistes reticulatus. Trans. Amer. Microsc. Soc., 82: 59. 
Fairbanks, U. F. 1967. Copper sulphate-Induced haemolytic anaemia. Arch. Intern. Med., 120: 428 .

Fujiya, M. 1960. Effects of copper dissolved in sea water on oysters. Bull. Jap. Soc. fish., 26: 462 .

Goodman, A. G. and F. Gilman. 1956. The Pharmacological Basis of Therapeutics. New York: Macmillan Co. Hubschmann, J. H. 1967. Effects of copper on the Crayfish Oronectes rusticus (Girard). II the mode of toxic action. Crustaceana. 12: 14I.

Hughes, G. M. and A. V. Grimstone. 1965. The fine structure of the secondary lamellae of the gill of Gadus pollachius. Quart. J. Micr. Sci. 106 (4): 343. Kessel, R. G. and H. W. Beams. 1962. Electron microscopy studies on the gill filaments of Fundulus heteroclitus from sea water and fresh water with special reference to the ultrastructural organization of the chloride cell. J. Ultra. Res. $\underline{6}: 7$.

Munshi, J.S. 1964. Chloride cells in the gills of fresh water teleosts. Quart. J. Microsc. Sci. 105 (1): 79.

Newstead, J. D. 1967. Fine structure of the respiratory lamellae of teleostean gills. Z. für Z. 79: 396. Peisach, J., P. Aisen and W.E. Blumberg (ed.). 1967. The Biochemistry of Copper. New York: Academic Press.

Peters, J. 1967. Effects of copper on pigeon brain. In Peisach et al., The Biochemistry of Copper. New York: Academic Press. 
Phillpott, H. C.W. and D. E. Copeland. '1963. Fine structure of chloride cells from three species of Fundulus. J. Cell Biol., 18: 389 .

Reynolds, E. S. 1963. The use of lead citrate at high pH as an electron opaque stain in electron microscopy. J. Cell Biol., 17: 208.

Scheinberg, I. H. and I. Sternleib. 1960. Copper metabolism. Pharm. Rev. 12: 355.

Sprague, J. B. 1964. Iethal concentration of copper and zinc solutions in young Atlantic salmon. J. Fish. Res. Bd. of Canada. 21 (1): 17 .

Sprague, J. B. and B. A. Ramsey. 1965. Lethal levels of mixed copper-zinc solutions for juvenile salmon. J. Fish. Res. Bd. of Canada. 22 (2): 425 .

Verity, M. A., L. K. Gambell, A. R. Reith and W. J. Brown. 1967. Subcellular distribution and enzyme changes following subacute copper intoxication. Lab. Investigation. $16(4): 580$.

Vogel, F. S. 1459. The deposition of exogenous copper under experimental conditions with observations on its neurotoxic and nephrotoxic properties in relation to Wilson's disease. J. Exp. Med. 110: 801. 